\title{
Monitoring of adaptive potential by functional loads and feeding regime of sturgeon juveniles
}

\author{
Lina Lagutkina ${ }^{1, *}$, Anna Bakhareva ${ }^{1}$, Aliya Akhmedzhanova ${ }^{1}$, Yulia Fedorovykh ${ }^{1}$ and \\ Evgenia Kuzmina ${ }^{1}$ \\ ${ }^{1}$ Astrakhan state technical University, 16, Tatishev str., 414056, Astrakhan, Russia
}

\begin{abstract}
The article presents the results of research on the physiological and biochemical state of sturgeon juveniles using various functional loads at the early stages of post-embryonic development of sturgeon raised on an experimental diet in the presence of live food. The article analyzes the effectiveness of the application of functional load methods and feeding regimen to establish the physiological status of released juveniles to replenish natural populations. The article provides information about the stability of young sturgeon fish during the period of release from sturgeon hatcheries to replenish the natural population, further entry from fresh to sea water, and placement in places of natural feeding. The temperature and salinity of water for hydrobionts is a factor that has an integral effect on the activity of functionally important systems of the body at all stages of the life cycle. Juveniles obtained from artificial generations and grown in a combined way on various feeds retain high plasticity, adequate nutrition forms an osmoregulatory function and resistance to temperature conditions of the environment. It is proved experimentally that the feeding regime is an important factor affecting the fish-breeding and biological and physiological and biochemical parameters of young Russian sturgeon, stellate sturgeon and bester.
\end{abstract}

\section{Introduction}

Sturgeon fish have a special status among aquatic biological resources [1-2]. Until recently, one of the most important fisheries reservoirs in Russia, which is characterized by high biological productivity of these unique fish, was the Caspian sea.

In connection with significant anthropogenic impact on the ecosystem of the Volga, the lack of simultaneous support in the lower reaches of the Volga river during the spring floods required volume flow at the appropriate time; an extended implementation of the high cost of water from the Volgograd hydroelectric appropriate temperature of water in the Volga river with spawning period temperature; increased thermal pollution, temperature and salt optimum, long-lasting temperature increase of the water; relevance of assessment and mandatory monitoring of resistance to stress loads of sturgeon juveniles produced at fish hatcheries.

\footnotetext{
${ }^{*}$ Corresponding author: lagutkina_lina@mail.ru
} 
To take into account these factors and their dynamics, it is necessary to implement a strategy for adaptation to climate [1] based on data from complex physiological and fishbreeding and biological studies that characterize the optimal zones of the organism's functioning. In this regard, the most important condition for obtaining high-quality fish products when growing sturgeon juveniles is to create such conditions under which the parameters of the released juveniles contributed to the viability in a changing natural environment [3-6]. Thus, when growing sturgeon fish farms, it is necessary to strictly observe all the biotechnical stages, perform agromeliorative work in inter-fish seasons with the implementation of the main techniques for the operation of growing ponds, provide a stable feed base, paying special attention to the nutrition of juveniles at the stage of rearing [6], on specialized feed directed action, increasing the adaptive potential of objects. According to many authors, an important factor that must be taken into account is adequate nutrition, feed recipes, nutrition regimes, feed and food additives that are part of the proposed feed [8-15].

Taking into account the available data [8-16], the characteristics reflecting the ecological and physiological optima of life activity in some sturgeon fish were additionally monitored on the studied species and in the conditions of growing on specialized feeds of directed action that increase the viability.

\section{Research material and methods}

Experimental work was carried out on the basis of the Sergiev sturgeon fish breeding hatchery of the Federal state budgetary institution "Glavrybvod" for artificial reproduction during fish breeding seasons. The object of the study was larvae, juveniles of Russian sturgeon, stellate sturgeon and bester, grown using pond and combined methods, an experimental diet based on local raw materials, and live food of Streptocephalus (Streptocephalus torvicornis).

\subsection{Method of functional loads at the early stages of postembryonic development by studying the thermoresistance of sturgeon fish}

To study the resistance to thermal factor loads, a special fish tank is used, preferably made of organic glass with an optimal capacity of 50-80 L (Fig.1).

The features of studying the thermoresistance of different-aged sturgeon fish are as follows. A batch of larvae or fry in the amount of 12 pcs - (small sample) or more than 33 pcs - (large sample) is deposited in a mesh cage installed in a fish tank filled with water. After that, the initial water temperature is measured, the active reaction of the medium is determined, the oxygen concentration is determined using an oximeter or titration method, i.e. the main physical and chemical parameters of the medium are monitored. In order to avoid various kinds of artifacts, experienced fry is kept in water before the experiment, which will fill the fish tank. At the same time, the fry does not feed for 18-24 hours before the experiment. After landing in a fish tank, the aquaculture objects are kept for 1-2 hours, after which the water heater is turned on. The rate of temperature increases to sub-zero should be within 50-60 minutes.

During the experiment, it is necessary to pay attention to the following: to note the features of the behavior of fry under stress, i.e. under conditions of a sharp rise in temperature. This is manifested as follows: phase 1-a gradual increase in motor activity; phase 2-the overwhelming number of fry maximum motor activity with rapid breathing. Individual individuals sink to the bottom of the cage; phase 3-complete inhibition of motor activity, suppression of respiratory function, i.e. movements of the opercular (gill) covers, followed by death. 


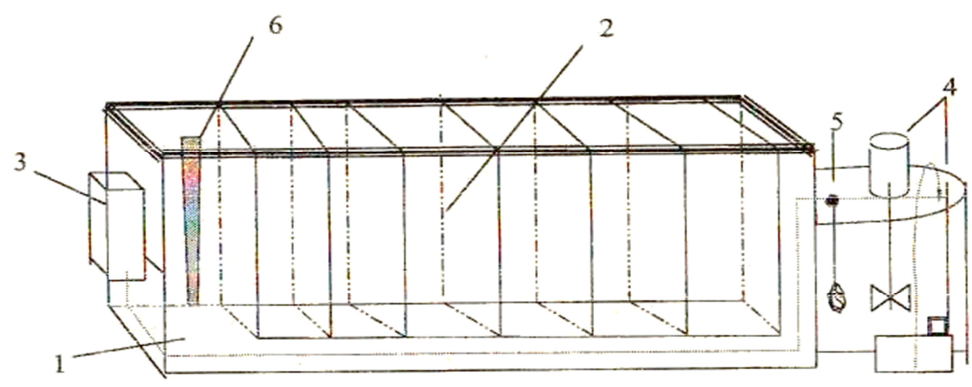

Fig. 1. Scheme for studying the thermoresistance of sturgeon larvae and juveniles.

Designations: 1-fish tank, 2-section mesh tank, 3-control panel, 4-electric aerator and microcompressor, 5 water heater, b-contact thermometer.

At the same time, it is necessary to note one feature. When working with larvae, it is visually difficult to determine the moment of death. To do this, it is advisable to use a glass stick with a blunt end. When you touch the body of a larva lying at the bottom of the cage, you can observe convulsive movements with this stick. In the absence of such a reaction, it is possible to judge the onset of a lethal outcome, while recording the time of survival. After the end of the experiment, all experienced larvae or fry are weighed and checked, and the data is recorded in the log for further processing by mathematical statistics [8].

\subsection{Method of functional loads at the early stages of postembryonic development by studying salt stability of sturgeon fish}

To study the salt resistance of sturgeon in the early stages of their post-embryonic development, sea water or salt is used, as well as artificially prepared ringer's solution. For example, a working solution with a salinity of $12 \%$ includes NaCl-11.6 g / 1, KC1 -0.12 $\mathrm{g} / \mathrm{l}, \mathrm{CaC} 1-0.36 \mathrm{~g} / \mathrm{l}, \mathrm{NaHCO} 3-0.24 \mathrm{~g} / \mathrm{l}$. Other salinity concentrations are prepared based on the proportional ratio of these components based on the total of these salts of $1 \mathrm{~g} / \mathrm{l}$ of fresh water. Aquariums or small-capacity tanks can be used as reservoir (for example, ITZA-1 tanks). Compressor units with air sprayers are used to maintain normal oxygen saturation. If the experiment lasts more than one day, the salt solution is updated with the newly prepared one (Fig. 2 and Fig. 3).

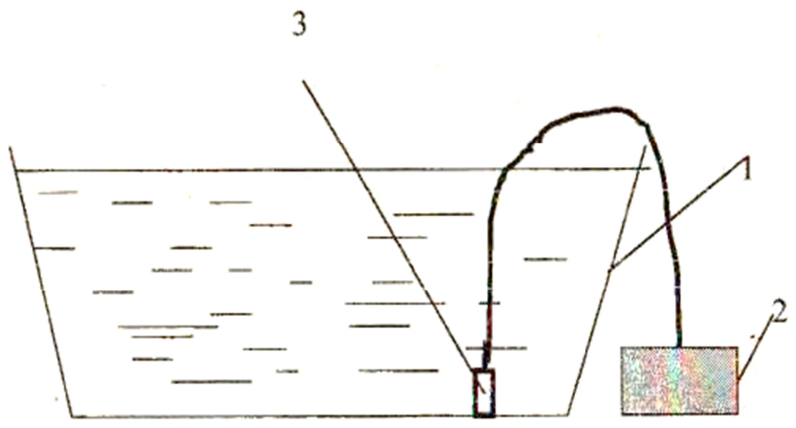

Fig. 2. General view of the tank for studying salt resistance of fish.

Designations: 1-tank, 2-compressor unit, 3-air sprayer.

During the experiment, the main physical and chemical parameters of the environment are monitored: temperature, oxygen saturation, $\mathrm{pH}, \mathrm{CO}_{2}$, nitrite and nitrate nitrogen, etc. 
Special attention is paid to the behavior of fry or larvae, or rather the phase of reactions to the effect of salinity. The experiment data is logged.

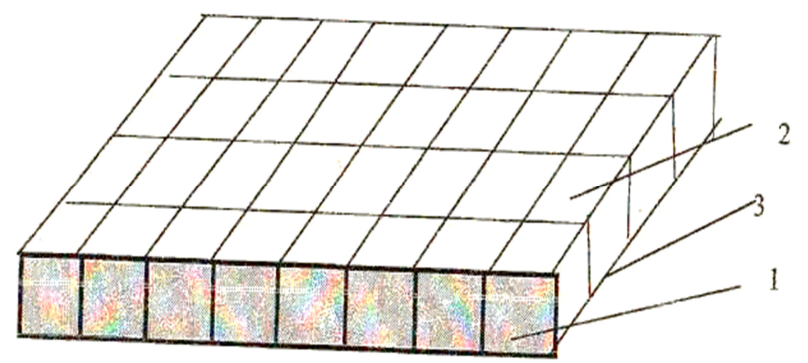

Fig. 3. General view of a mesh cage for studying salt resistance of sturgeon larvae and juveniles.

Designations: 1 - General view of the cage; 2-cells; 3-stiffeners.

All data was subjected to statistical processing using the Excel stat analysis software panel. At the same time, we used elements of statistical analysis to determine the average and the average error. The level of differences was evaluated using the Student's confidence criterion.

\section{Research results}

The state of the thermal regime depends on the intensity of general and generative exchanges in fish, the duration and typical development of the organism in early ontogenesis, the activity of life, nutrition and growth rates. Therefore, one of the criteria for assessing viability in the larval and juvenile periods of development in our experiments was the influence of sublethal temperatures at the stage of transition to exogenous nutrition and during the active phase of various feeding regimes.

Sturgeon is an extremely important and valuable object for studying thermal adaptation, primarily because their thermal niche in the range of life temperature values does not coincide with the thermal niches of many other freshwater species (carp, perch, whitefish and salmon). on the other hand, when released from artificial conditions into natural ones, it is necessary to assess the adaptive capabilities of the grown young.

Moreover, the study of temperature adaptations of sturgeon raised on different feeding regimes reveals optimal feeding conditions, which is extremely important for the needs of aquaculture, as well as for solving issues of artificial reproduction of sturgeon herds.

Therefore, we studied the thermoregulatory behavior of young stellate sturgeon, which was studied in early ontogenesis by the method of functional loads on the body, shown in figure 4 . 


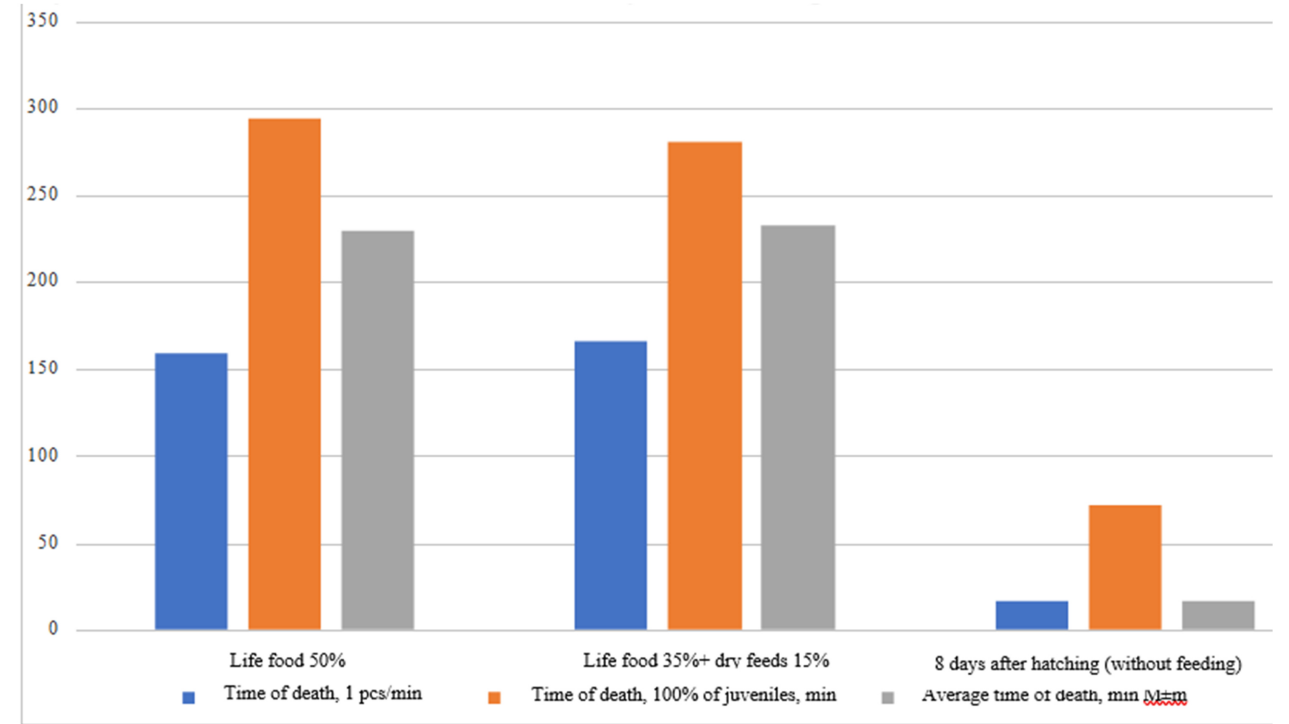

Fig. 4. The mortality rate of juveniles of stellate sturgeon thermal exposure.

It should be noted that stellate sturgeon is the most resistant among sturgeon to high temperatures. After a heat load of $+32^{\circ} \mathrm{C}$, the undergrown juveniles in pond unstable hydrobiological conditions for half an hour and further transfer to $+10^{\circ} \mathrm{C}$ conditions, adaptation occurs in 10 minutes. In our experiments, we should note the high thermal stability of undergrown juveniles, the survival time was 13 times higher compared to ungrown larvae, the values were in young stellate sturgeon with a mass of $60-70 \mathrm{mg}$ grown on live feed$229.9 \pm 13.4 \mathrm{~min}$, on live and dry feed $233.2 \pm 15.4 \mathrm{~min}$, and without feeding this is 8 days from the day of hatching $17.2 \pm 8.11 \mathrm{~min}$. Thus, the thermoregulatory behavior of young sturgeon at the age of 7 days after hatching has a high value of the temperature optimum of $25+2 \mathrm{C}$, in comparison with other species, which is a recommendation for growing young sturgeon in the conditions of using feeding modes. Thus, it is shown that periodic fluctuations of environmental factors within the ecological norm and when growing larvae with $50 \%$ live food accelerate growth and post-embryonic development, optimize energy, improve the overall physiological state, and increase vitality.

One of the limiting factors of the aquatic environment for passing sturgeon fish that live in various reservoirs is the salinity of sea water. The study of the ability to adapt to changes in salinity in fish species that differ in their ecological and physiological characteristics is one of the most relevant areas of research. The ability to maintain ionic homeostasis in a hypo-and hyperosmotic environment allows representatives of different species to migrate with a change of habitat, to populate reservoirs that have differences in mineral composition. At the same time, the study of salt resistance in various fish allows us to make recommendations aimed at optimizing the reproduction process, measures to increase the survival rate of juveniles, in artificial conditions under different feeding regimes. A study of salt tolerance of young sturgeon fish, has high resilience grown up stellate sturgeons on a live and dry feed, in contrast to the juvenile without feeding (Fig 5,6). 


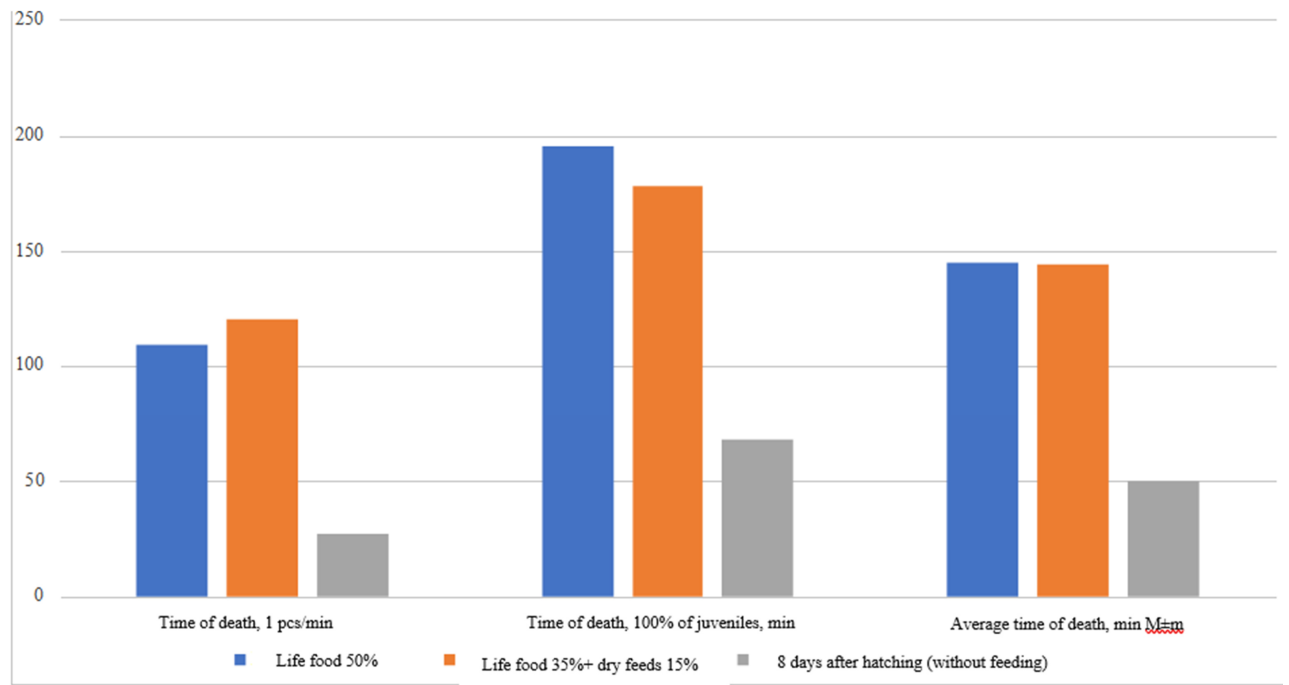

Fig. 5. The mortality rate of juvenile stellate sturgeon with salt shock.

The obtained results of salt resistance studies allow us to recommend the use of $50 \%$ of live feed in the diet of juveniles. The results of the research can be used in the development of biotechnology for growing and reproducing sturgeon in artificial conditions using water of different salinity.

Experimental data confirmed that the thermoresistance and salt resistance of ungroomed stellate sturgeon larvae is the lowest. The increase in the level of thermoresistance and salt resistance occurs in 8-day-old juveniles (from the day of exogenous feeding) with a significant $(\mathrm{p}<0.001)$ difference from ungroomed larvae.

Based on our own observations of Russian sturgeon and stellate sturgeon larvae growing and matching the data obtained with those of other authors [17], we found that early juveniles must pass a critical period of post-embryonic development: the period of transition to exogenous nutrition under control when growing in tanks in special feeding regimes with the availability of live feed. In addition, natural culling of batches of nonviable planting larvae occurs during tank cultivation, and it is impossible to control this process in pond conditions.

In a further series of experimental work, it is necessary to establish the physiological status of sturgeon juveniles that consumed dry mixed feeds, which were kept under intensive cultivation with the use of combined feeding, both dry and live feeds are used for growing resilient material and replenishing natural populations.

Dry combined feeds, as well as live ones, contain lipids that can affect the lipid composition of the body of the reared young. Lipids are responsible for the permeability of cell membranes and the intensity of metabolic processes. The bulk of the lipids are triacylglycerols, they are rich in fatty tissue. Since they play an energy role, the renewal process is faster than that of complex lipids (phospholipids and others). The latter are part of biological membranes, their renewal is associated with the restoration of the damaged section of the membrane. In the synthesis of (triacylglycerols, phospholipids) are fatty acids (tab. 1). 
Table 1. Composition of total fatty acids of phospholipids, triacylglycerides of Russian sturgeon juveniles, (\%).

\begin{tabular}{|c|c|c|c|c|}
\hline \multirow{2}{*}{ Fatty acids } & \multicolumn{2}{|c|}{ Phospholipids } & \multicolumn{2}{c|}{ Triacylglycerides } \\
\cline { 2 - 5 } & $\begin{array}{c}\text { experimental diet } \\
\text { + live food }\end{array}$ & $\begin{array}{c}\text { experimental } \\
\text { diet }\end{array}$ & $\begin{array}{c}\text { experimental } \\
\text { diet + live food }\end{array}$ & $\begin{array}{c}\text { experimental } \\
\text { diet }\end{array}$ \\
\hline Saturated & $27.5 \pm 2.1$ & $26.8 \pm 1.8$ & $31.4 \pm 1.5$ & $32.7 \pm 1.7$ \\
\hline Unsaturated & $72.5 \pm 2.3$ & $73.2 \pm 2.1$ & $68.6 \pm 1.8$ & $67.3 \pm 1.5$ \\
\hline Monoene & $41.6 \pm 0.8$ & $42.3 \pm 0.7$ & $40.4 \pm 0.8$ & $40.1 \pm 0.5$ \\
\hline Polyene & $30.9 \pm 0.4$ & $30.9 \pm 0.5$ & $28.2 \pm 0.3$ & $27.2 \pm 0.3$ \\
\hline$\Sigma \mathrm{w} 3$ & $25.1 \pm 0.7$ & $24.8 \pm 0.3$ & $17.0 \pm 0.1$ & $14.4 \pm 0.4$ \\
\hline$\Sigma \mathrm{w} 6$ & $5.8 \pm 0.3$ & $6.1 \pm 0.4$ & $11.2 \pm 1.2$ & $12.8 \pm 1.6$ \\
\hline$\Sigma \mathrm{w} 3 / \Sigma \mathrm{w} 6$ & $4.3 \pm 0.2$ & $4.1 \pm 0.1$ & $1.5 \pm 0.4$ & $1.1 \pm 0.6$ \\
\hline
\end{tabular}

Indicators of the composition of phospholipids, triacylglycerides of lipids of juveniles grown by the combined method and juveniles grown by the pond method were quite close. It should be noted equally high levels of physiologically valuable polyene fatty acids in phospholipids, triacylglycerides of the body of fish that consumed live feed and starting feed with FA. A high degree of polyunsaturated fatty acids indicates the formation of temperature adaptation of juveniles. Similar data were obtained by comparing phospholipid spectra (table 2) and the fractional composition of total lipids (table 3).

Table 2. Phospholipid spectrum of total lipids in Russian sturgeon juveniles at the end of cultivation,

(\%).

\begin{tabular}{|l|l|c|c|}
\hline \multicolumn{1}{|c|}{ Indicators } & \multicolumn{1}{|c|}{ Characteristic } & $\begin{array}{c}\text { Experimental } \\
\text { Diet + Live } \\
\text { Food }\end{array}$ & $\begin{array}{c}\text { Experimental } \\
\text { Diet }\end{array}$ \\
\hline Inosinephosphatides & $\begin{array}{l}\text { They are found mainly in the brain } \\
\text { of humans and animals. where } \\
\text { they play an important role in } \\
\text { nervous activity. }\end{array}$ & $0.5 \pm 0.1$ & $0.5 \pm 0.1$ \\
\hline Lysophosphatidylcholines & $\begin{array}{l}\text { They are found mainly in cell } \\
\text { membranes. }\end{array}$ & $0.5 \pm 0.1$ & $0.5 \pm 0.1$ \\
\hline Sphingomyelins & $\begin{array}{l}\text { They are found in large quantities } \\
\text { in the nervous tissue. as well as in } \\
\text { the blood and vital organs of the } \\
\text { body. Quantity-10-12\%. }\end{array}$ & $7.2 \pm 0.4$ & $6.4 \pm 0.3$ \\
\hline Phosphatidylcholines & $\begin{array}{l}\text { They make up 50\% of cell } \\
\text { membrane lipids. Included in the } \\
\text { lipoproteins of blood. }\end{array}$ & $55.9 \pm 3.2$ & $37.2 \pm 4.1$ \\
\hline Phosphatidylserines & $\begin{array}{l}\text { Found in most animal. plant. and } \\
\text { bacterial tissues }\end{array}$ & $3.1 \pm 0.2$ & $3.4 \pm 0.2$ \\
\hline Phosphatidylethanolamines & $\begin{array}{l}\text { It belongs to one of the most } \\
\text { common groups of } \\
\text { phosphoglycerides of all } \\
\text { intracellular membranes of animal } \\
\text { and plant cells. They make up } \\
\text { about 20\% of the total lipids. }\end{array}$ & $32.5 \pm 2.1$ & $31.7 \pm 2.4$ \\
\hline $\begin{array}{l}\text { Polyricinoleate and } \\
\text { cardiolipin }\end{array}$ & $\begin{array}{l}\text { They are found in many animal } \\
\text { and human tissues. in the green } \\
\text { leaves of higher plants. and in } \\
\text { yeast. The content of 2-5\% of all } \\
\text { phospholipids. In mitochondrial } \\
\text { membranes. they are the main } \\
\text { component of phospholipids. }\end{array}$ & $0.5 \pm 0.2$ & $0.3 \pm 0.5$ \\
\hline
\end{tabular}


The phospholipid spectra of the experimental and control groups of fish corresponded to the norms for assessing the physiological full-fledged status [17] and were very close.

Table 3. Fractional composition of total lipids in Russian sturgeon juveniles at the end of cultivation, $(\%)$

\begin{tabular}{|l|l|c|c|}
\hline \multicolumn{1}{|c|}{ Indicators } & \multicolumn{1}{|c|}{ Functions } & $\begin{array}{c}\text { Experimental Diet } \\
\text { + Live Food }\end{array}$ & $\begin{array}{c}\text { Experimental } \\
\text { Diet }\end{array}$ \\
\hline Triacylglycerols & $\begin{array}{l}\text { Mechanical: protects organs from } \\
\text { damage; thermal insulation: retains } \\
\text { heat; solvent. }\end{array}$ & $46.6 \pm 3.4$ & $44.2 \pm 2.8$ \\
\hline Phospholipids & $\begin{array}{l}\text { Structural: form the lipid base of cell } \\
\text { membranes; transport: transport of } \\
\text { substances (such as carotenoids) } \\
\text { through the lipid layer of the } \\
\text { membrane. }\end{array}$ & $29.1 \pm 1.6$ & $27.4 \pm 1.5$ \\
\hline Cholesterol & $\begin{array}{l}\text { Structural: the building of membranes } \\
\text { in cells. Cholesterol forms important } \\
\text { steroid compounds: bile acids. } \\
\text { hormones. and vitamin D } . ~\end{array}$ & $11.8 \pm 0.8$ & $11.7 \pm 0.8$ \\
\hline Cholesterol esters & $\begin{array}{l}\text { Structural: Form the lipid base of } \\
\text { biological membranes. }\end{array}$ & $7.1 \pm 0.4$ & $8.4 \pm 0.6$ \\
\hline Monoacylglycerides & $\begin{array}{l}\text { Substrate-energy: when 1g lipids are } \\
\text { burned. 39.1 kJ is released. The } \\
\text { content increases the phase of } \\
\text { functional activity of the body. the } \\
\text { phase of cell regeneration. }\end{array}$ & $2.0 \pm 0.2$ & $2.5 \pm 0.3$ \\
\cline { 2 - 4 } Diacylglycerols & $\begin{array}{l}\text { Vitamin function. Regulate excessive } \\
\text { deposition of triacylglycerols. They } \\
\text { are not formed in the body and must } \\
\text { come with food. }\end{array}$ & $2.4 \pm 0.3$ & $2.6 \pm 0.4$ \\
\hline Non-esterified fatty \\
acids
\end{tabular}

Thus, the most important indicators of the full physiological status of young fish are data on the content of triacylglycerines and phospholipids. They were quite high in experience and control. This indicates that the cell membranes and structural lipids of the fish organism allow Russian sturgeon juveniles to make food migrations, overcome adverse environmental factors, including adapting to unstable thermal conditions.

Very reliable indicators that characterize the physiological state of fish should also be considered data on the general chemical composition of the body. Thus, the juveniles of Russian sturgeon and stellate sturgeon grown by pond method were characterized by the following data (table. 4).

Table 4. Total chemical composition of the body of Russian sturgeon and stellate sturgeon juveniles.

\begin{tabular}{|c|c|c|c|c|}
\hline \multirow{2}{*}{ Variants } & \multirow{2}{*}{ Moisture. \% } & \multicolumn{3}{|c|}{ Absolutely dry substance. \% } \\
\cline { 3 - 5 } & Protein & Fat & Ash \\
\hline $\begin{array}{c}\text { Pond method } \\
\text { (Russian sturgeon) }\end{array}$ & $90.8 \pm 2.1$ & $63.8 \pm 1.6$ & $9.9 \pm 2.1$ & $11.3 \pm 0.5$ \\
\hline $\begin{array}{c}\text { Pond method } \\
\text { (stellate sturgeon) }\end{array}$ & $90.3 \pm 1.8$ & $64.6 \pm 1.3$ & $8.8 \pm 0.7$ & $11.0 \pm 0.4$ \\
\hline
\end{tabular}

Russian sturgeon and stellate sturgeon juveniles by chemical composition of the body, grown by a combined method with germination on experimental feeds in the presence of live feed, mainly differed in higher protein content at $(\mathrm{p}<0.01)$ in comparison with young, grown by pond method (table 5), this indicates a good physiological state of the objects 
being grown, since a high level of protein corresponds to a good state of the growing conditions.

Table 5. Total chemical composition of the body of Russian sturgeon and stellate sturgeon juveniles.

\begin{tabular}{|c|c|c|c|c|}
\hline \multirow{2}{*}{ Variants } & \multirow{2}{*}{ Moisture. \% } & \multicolumn{3}{|c|}{ Absolutely dry substance. \% } \\
\cline { 3 - 5 } & Protein & Fat & Ash \\
\hline $\begin{array}{l}\text { Combined method } \\
\text { Russian sturgeon) }\end{array}$ & $91.3 \pm 2.2$ & $69.7 \pm 1.5$ & $11.7 \pm 0.8$ & $12.3 \pm 0.6$ \\
\hline $\begin{array}{l}\text { Combined method } \\
\text { (stellate sturgeon) }\end{array}$ & $91.4 \pm 2.0$ & $68.9 \pm 1.7$ & $11.6 \pm 0.8$ & $13.1 \pm 0.5$ \\
\hline
\end{tabular}

Summarizing the above, we found that the physiological state of Russian sturgeon and stellate sturgeon juveniles grown by combined and pond methods was quite close and was characterized by optimal indicators. However, it is noticeable that the most active accumulation of nutrients occurred in young sturgeon grown by the combined method when growing on an experimental diet in the presence of live feed. This is an important factor that affects the formation of adaptive osmoregulation functions, the level of stability, the formed stress resistance of the organism to changing natural environmental conditions, which allows fish breeders to qualitatively select individuals for release to replenish natural populations of valuable fish species.

It should be considered that the physiological status of early Russian sturgeon and stellate sturgeon, grown both by combined and pond methods, was the same with good health indicators (high levels of protein, triacylglycerines, phospholipids). However, these differences were statistically uniform.

An additional important indicator of fish homeostasis is the level of fatty acids in total lipids, triacylglycerines, and phospholipids. Linolenic fatty acids are essential for many fish species and must be supplied with adequate food. Their content characterizes the quality of young fish grown in artificial conditions. Thus, the composition of the fatty acids of the total body lipids of the bester juveniles is influenced by the lipids that were contained in the feed (table 6).

Table 6. Composition of total fatty acids of triacylglycerines of bester juveniles at a weight of $3 \mathrm{~g}, \%$.

\begin{tabular}{|c|c|c|}
\hline \multirow{2}{*}{ Fatty acids } & \multicolumn{2}{|c|}{ Triacylglycerines } \\
\cline { 2 - 3 } & experimental diet + live food & experimental diet \\
\hline Saturated & $26.5 \pm 1.5$ & $28.4 \pm 1.8$ \\
\hline Unsaturated & $73.5 \pm 1.7$ & $71.6 \pm 1.5$ \\
\hline Monoene & $38.6 \pm 0.7$ & $35.4 \pm 0.8$ \\
\hline Polyene & $34.9 \pm 0.5$ & $36.2 \pm 0.5$ \\
\hline$\Sigma \mathrm{w} 3$ & 19.6 & 20.2 \\
\hline$\Sigma \mathrm{w} 6$ & 15.3 & 16.0 \\
\hline$\Sigma \mathrm{w} 3 / \Sigma \mathrm{w} 6$ & 1.3 & 1.3 \\
\hline
\end{tabular}

The indicators are quite similar in the fish of the two groups, which were grown both live and dry feed, and live, (the ratio of the sum of w3/w6 in both variants is 1.3).

Similar indicators of the composition of fatty acids in bester of these experimental groups were established in the analysis of phospholipids (table 7).

Table 7. Composition of total fatty acids of phospholipids of bester juveniles at a weight of $3 \mathrm{~g}, \%$.

\begin{tabular}{|c|c|c|}
\hline \multirow{2}{*}{ Fatty acids } & \multicolumn{2}{|c|}{ Phospholipids } \\
\cline { 2 - 3 } & experimental diet + live food & experimental diet \\
\hline Saturated & $34.5 \pm 2.1$ & $32.6 \pm 2.1$ \\
\hline Unsaturated & $65.5 \pm 2.2$ & $67.4 \pm 2.0$ \\
\hline Monoene & $42.2 \pm 0.7$ & $39.8 \pm 0.8$ \\
\hline
\end{tabular}




\begin{tabular}{|c|c|c|}
\hline Polyene & $23.1 \pm 0.4$ & $27.6 \pm 0.4$ \\
\hline$\Sigma \mathrm{w} 3$ & 13.3 & 15.6 \\
\hline$\Sigma \mathrm{w} 6$ & 9.8 & 12.0 \\
\hline$\Sigma \mathrm{w} 3 / \Sigma \mathrm{w} 6$ & 1.4 & 1.3 \\
\hline
\end{tabular}

This indicates that the fatty acid composition of triacylglycerols and phospholipids in fish of the two experimental groups are very close. It is known that fish that consume live food are healthy [16]. Attention is drawn to the data on the content of essential fatty acids of the linolenic (w 3) series, which positively characterizes the quality of grown fish.

The general chemical composition of bester's juveniles is very indicative. it also allows us to assess the physiological status of the fish-planting material (table 8).

Table 8. Total chemical composition of the body of bester juveniles weighing $3 \mathrm{~g}, \%$.

\begin{tabular}{|c|c|c|c|c|}
\hline \multirow{2}{*}{ Variants } & \multirow{2}{*}{$\begin{array}{c}\text { Moisture, } \\
\text { \% }\end{array}$} & \multicolumn{3}{|c|}{ Absolutely dry substance, \% } \\
\cline { 3 - 5 } & $88.4 \pm 2.2$ & Protein & Fat & Ash \\
\hline experimental diet + live food & $85.3 \pm 1.8$ & $18.6 \pm 0.5$ & $11.5 \pm 0.5$ \\
\hline live food & $90.1 \pm 2.1$ & $63.4 \pm 1.8$ & $19.3 \pm 0.7$ & $11.2 \pm 0.5$ \\
\hline
\end{tabular}

A higher amount of protein in the body of fish that consumed live and dry food should be considered very favorable. at the same time, it should be noted that the fish of both experimental groups had quite a lot of protein in the body (63-65\%).

Thus, the aggregate of such indicators as the composition of the total fatty acids of triacylglycerols, phospholipids, total chemical body composition of juvenile sturgeon, health status, physiological status of juveniles grown by combined method, high and not inferior to the group of fish from ponds that are used exclusively natural food.

Summarizing, the results of the research allow us to recommend the use of $50 \%$ of live feed in the diet of young sturgeon fish, since this feeding mode contributes to the osmoregulatory functions and thermal stability formed in young fish.

\section{References}

1. S.S.O. Hung, Animal Nutrition 3(3), 191-204 https://www.sciencedirect.com/science/article/pii/S2405654516302037

2. F. Jafari, N. Agh, F. Noori, A. Tokmachi, E. Gisbert, Fish \& Shellfish Immunology 80, 487-496 (2018)

3. M.-A. Blanchet, R. Primicerio, A. Smalåsa, J. Arias-Hansen, M. Aschana, Fisheries Research 209, 251-258 (2019) https://www.sciencedirect.com/ science/article/abs/pii/S016578361830239X

4. F.J. Tapiador, R. Moreno Andrés Navarro, Atmospheric Research 216, 26-36 (2019) https://www.sciencedirect.com/science/article/pii/S0169809518309025

5. W.R Travis, J.B. Smith, G.W. Yohe, Current Opinion in Environmental Sustainability 31, 146-152 (2018) https://www.sciencedirect.com/science/article/abs/pii/ S1877343517301045

6. X. Wang, D. Jiang, X. Lang, Science Bulletin 62(24), 1673-1680 (2017) https://www.sciencedirect.com/science/article/pii/S2095927317305583

7. N. Ghasemi, A. Imani, F. Noori, R. Shahrooz, Aquaculture 519(30), 734-751 (2020) https://www.sciencedirect.com/science/article/abs/pii/S004484861931556X

8. R. Akrami, Y. Irib, H. ali Khoshbavar Rostami, M. Razeghi Mansour, Fish \& Shellfish Immunology 35(4), 1235-1239 (2013) https://www.sciencedirect.com /science/article/abs/pii/S1050464813006773 
9. F. Taridashti, K. Delafkar, A. Zare, G. Azari-Takami, Journal of Applied Aquaculture 29(3-4), 220-232 (2017) https://doi.org/10.1080/10454438.2017.1363112

10. M. Sudagar, A. Hajibaglo, M. Ali Jalali, H. Kolangi Miandare, Journal of Applied Aquaculture 24(1), 81-87 (2012) https://doi.org/10.1080/10454438.2012.652040

11. S. Lee, S.S.O. Hung, N.A. Fangue, L. Haller, A.E. Todgham, Comparative Biochemistry and Physiology Part A: Molecular \& Integrative Physiology 198, 87-95 (2016)

12. M.F. McLean, M.K. Litvak, E.M. Stoddard, S.J. Cooke, D.A. Patterson, S.G. Hinch, D.W. Welch, G.T. Crossin, Comparative Biochemistry and Physiology Part A: Molecular \& Integrative Physiology 240, $110618 \quad$ (2020) https://doi.org/10.1016/j.cbpa.2019.110618

13. L. Luoa, T. Lia, W. Xinga, M. Xueb, Z. Maa, N. Jianga, W. Lia, Aquaculture 448, 229-233 (2015) https://doi.org/10.1016/j.aquaculture.2015.06.005

14. C. Lane, E.J. Livengood, R.D. Miles, F.A. Chapman, Journal of Applied Aquaculture, 30(1), 39-46 (2017) https://doi.org/10.1080/10454438.2017.1413478

15. F. Jafari, N. Agh, F. Noori, A. Tokmachi, E. Gisbert, Fish \& Shellfish Immunology 80, 487-496 (2018) https://www.sciencedirect.com/science/article/abs/pii/ S1050464818303644

16. J. Fedorovykh, S. Ponomarev, J. Bakaneva, J. Sergeeva, A. Bakhareva, J. Grozesku, V. Egorova, Journal of Aquaculture research and development 6 (2015) https://www.longdom.org/archive/jard-volume-6-issue-5-year-2015.html

17. M.S. Chebanov, E.V. Galich, Fisheries and aquaculture technical paper, Sturgeon Hatchery Manual 558 (2013) http://www.fao.org/3/a-i2144e.pdf 